\title{
Methodological Investigations on a Neuropteroidea Community
}

\author{
J. VAS ${ }^{1}$, L. ÁBRAHÁM ${ }^{2}$ and V. MARKÓ ${ }^{1}$ \\ ${ }^{1}$ Department of Entomology, University of Horticulture and Food Industry, Budapest, Hungary \\ ${ }^{2}$ Somogy County Museum, Kaposvár, Hungary
}

The same Neuropteroidea community was collected and studied in Hungary in the years 1991 and 1992 by using different trapping techniques: a) Malaise trap, b) suction trap, c) yellow pan trap and d) light trap. The studies aimed to compare the different sampling methods for individual species, families and for the whole Neuropteroidea community.

In case the whole Neuropteroidea community the trapped individual numbers collected by the suction trap surpassed all other trap types. Relatively high numbers of Neuropteroidea could be collected both by light trap and Malaise traps. The yellow pan traps did not succeed in catching large enough samples neither from point of view of sample size nor from species richness. According to the number of species collected there were not discovered any big difference between the catches of suction trap, Malaise traps and light trap.

By evaluating according to families it was stated that in case of the family Raphidiidae the Malaise trap yielded larger and more diverse samples than any other methods; however by increasing the number of yellow pan traps it is possible to augment the number of caught individuals. The suction traps were found very satisfactory in collecting members of the family Coniopterygidae. For the members of the families Hemerobiidae and Chrysopidae both the suction traps and light traps were found effective, although suction traps were more successful in collecting Chrysopidae species.

Similarly, by evaluating the data according to individual species it was found that the Malaise traps tended to "under-represent" species belonging to Hemerobius humulinus, Hemerobius Lutescens, Chrysopa pallens and the ones belonging to Chrysoperla carnea complex compared to the suction trap. The opposing situation was perceived with Micromus lanosus and Chrysopa perla. Similarly - compared to suction trap - the light trap significantly "under-represented" the species Hemerobius humulinus, Hemerobius lutescens, Chrysopa pallens, Chrysoperla carnea and Dichochrysa prasina and "over-represented" Micromus angulatus, Sympherobius pygmaeus and Chrysopa phyllochroma.

The diversity of Neuropteroidea collected by Malaise trap and light trap surpassed significantly the one of suction trap and yellow pan traps. The assemblages collected by different sampling methods showed some overlapping, but differed in their characters.

Keywords: Raphidiidae, Coniopterygidae, Hemerobiidae, Chrysopidae, sampling techniques, Malaise trap, suction trap, light trap, yellow pan trap.

Many ingenious instruments have been devised that are successful in catching large quantities of insect taxonomical groups but only a few of these are suited for quantitative insect sampling (Muirhead-Thomson, 1991). A theoretically good sampling technique has to represent the structure of a community without deformations. From technical point of view our instruments have been brought gradually near to perfection, but in spite of this it still has to be said that our quantitative collections often reflect only the minimal values of the majority of the species occurring in the ecosystem (Balogh, 1953).

Looking over the investigations on the Neuropteroidea assemblages either in natural or in agricultural ecosystems it seems that from methodological point of view this group has not been studied with the same intensity as some other groups like Coleoptera 
and Lepidoptera (Muirhead-Thomson, 1991). To the community surveys, sweeping nets, light traps, Malaise traps, pan traps, sticky traps, McPhail traps and suction traps were used and these assessments were carried out mostly against adults (Banks, 1952; Canard et al., 1979; Greve and Andersen, 1975; New, 1967; Szabó and Szentkirályi, 1981; Szentkirályi, 1992; Sziráki, 1996).

\section{Materials and Methods}

Our studies have carried out in 1991 and 1992 in the experimental orchard of the Plant Protection Institute of the Hungarian Academy of Sciences near Budapest (Nagykovácsi, Juliannna-major, North latitude: $47^{\circ} 30^{\prime}$ and East longitude $19^{\circ}$; UTM: CT47). The mixed, abandoned orchard with secondary succession lies in the Buda Hills on $470 \mathrm{~m}$ height above the sea level, surrounded by oak forests (Quercetum petreae-cerris and Ceraso-mahaleb-quercetum pubescentis) and ruderal vegetation. The two-hectare orchard containing different fruit species and varieties was established in 1967 and had not received since 20 years any plant protection treatments. Earlier faunistical studies were carried out in the orchard by Szabó and Szentkirályi (1981).

One Meszlény and Szalay-Marzsó (1979) type suction trap was placed on the edge of the orchard, near to peach trees. The engine of the trap operated on $220 \mathrm{~V}(55 \mathrm{~W})$ and had a capacity of $1000 \mathrm{~m}^{3}$ airflow per hour. The mouth of the aspirator was $48 \mathrm{~cm}$ in diameter and worked in a height of $160 \mathrm{~cm}$. The trap was emptied twice daily, in the morning and evening twilight.

Two white coloured Thownes-type Malaise traps (Townes, 1962; Móczár, 1967) were used, one in the centre of the orchard, $40 \mathrm{~m}$ distance from the edge, the other on the edge of the orchard near of an oak forest, $20 \mathrm{~m}$ distance from the suction trap. The height of the traps was $3.5 \mathrm{~m}$ with catching area of $10 \mathrm{~m}^{2}$.

One Jermy type (Jermy, 1961) light trap was used $40 \mathrm{~m}$ distance from the edge, not too far from the second Malaise trap. It was attached $1.8 \mathrm{~m}$ above the ground and operated with $100 \mathrm{~W}$ lamp and emptied daily in 1991. The Coniopterygidae from the material collected by light trap were not separated.

Five yellow pan traps were placed into the orchard at height $1.5 \mathrm{~m}$. Two pans were placed near the suction trap, and one near all the other type traps. Each trap $(14 \mathrm{~cm} \times 20$ $\mathrm{cm} \times 10 \mathrm{~cm}$ ) was halfway filled with $30 \%$ ethylene glycol in water. The yellow pan traps and Malaise traps were emptied three times a week. All the traps operated from mid-March until mid-November in both years.

In the characterisation of the Neuroptera assemblages the characters of species richness and diversity are generally used. As the different diversity indexes show wellknown different sensitivities towards the extremes: common and rare species, the lacewing assemblages were characterised by diversity ordering function, where a scale parameter $(\alpha)$ underwent continuous increasing. As a result we obtained the profile of diversity of the Neuropteroidea community from the low (sensitivity to rare species) to high (sensitivity to common species) scale parameters. For this diversity arrangement the one used by Rényi (1961) was chosen (Tóthmérész, 1995). 


$$
\begin{aligned}
& \mathrm{H} \alpha=\frac{\log \sum_{i=1}^{S} p_{i}^{\alpha}}{1-\alpha} \\
& \text { where } \quad \begin{array}{l}
\alpha=0, \alpha \neq 1 \\
S: \text { Total number of species } \\
p_{i}: \text { Percentage of species } i \text { in the total assemblage }
\end{array}
\end{aligned}
$$

Comparison of the samples of four different trap types and of two distinct years was performed by the program Syntax 5.1 using multivariate data analysis methods, namely hierarchical classification (complete linkage) and ordination (principal coordinates analysis - PCoA). Both the cluster analysis and the PCoA methods were based on Horn index (Krebs, 1989).

\section{Results}

In course of our survey 1849 individuals of 43 Neuroptera species were collected in total (Table 1). Considering the individual numbers the highest values were brought by the suction trap, followed by the light trap and Malaise traps (Tables 1 and 2). However, if the family Coniopterygidae is excluded, there are no significant differences between the number of species collected by the three methods (Tables 1 and 2). The collecting successes of the five yellow pan traps were left behind the other trap types.

\begin{tabular}{|c|c|c|c|c|c|c|c|}
\hline & \multicolumn{2}{|c|}{ Suction trap } & \multicolumn{2}{|c|}{ Malaise traps ${ }^{1}$} & \multicolumn{2}{|c|}{$\begin{array}{c}\text { Yellow } \\
\text { pan traps }\end{array}$} & \multirow{2}{*}{$\begin{array}{c}\text { Light } \\
\text { trap }^{3} \\
1991\end{array}$} \\
\hline & 1991 & 1992 & 1991 & 1992 & 1991 & 1992 & \\
\hline \multicolumn{8}{|l|}{ Raphidiidae } \\
\hline Dichrostigma flavipes Stein & 2 & 2 & 21 & 11 & 12 & 2 & 0 \\
\hline Raphidia ophiopsis Linnaeus & 0 & 0 & 0 & 2 & 1 & 0 & 0 \\
\hline Subilla confinis Stephens & 0 & 0 & 0 & 7 & 0 & 0 & 0 \\
\hline Xanthostigma xanthostigma Schummel & 0 & 0 & 9 & 11 & 0 & 0 & 0 \\
\hline \multicolumn{8}{|l|}{ Inocellidae } \\
\hline Inocellia crassicornis Schummel & 0 & 0 & 1 & 0 & 0 & 0 & 0 \\
\hline Parainocellia braueri Albarda & 0 & 0 & 1 & 0 & 0 & 0 & 0 \\
\hline \multicolumn{8}{|l|}{ Coniopterygidae } \\
\hline Coniopteryx arcuata $\mathrm{Kis}$ & 46 & 18 & 0 & 0 & 0 & 0 & - \\
\hline Coniopteryx borealis Tjeder & 4 & 19 & 0 & 0 & 0 & 0 & - \\
\hline Coniopteryx esbenpeterseni Tjeder & 54 & 150 & 0 & 0 & 0 & 0 & - \\
\hline Coniopteryx haematica McLachlan & 0 & 3 & 0 & 0 & 0 & 0 & - \\
\hline Coniopteryx lentiae Aspöck et Aspöck & 0 & 1 & 0 & 0 & 0 & 0 & - \\
\hline
\end{tabular}

Table 1

Individual densities of Neuroptera species in function of different collecting methods applied. Nagykovácsi, 1991 and 1992 
Table 1 (cont.)

\begin{tabular}{|c|c|c|c|c|c|c|c|}
\hline & \multicolumn{2}{|c|}{ Suction trap } & \multicolumn{2}{|c|}{ Malaise traps ${ }^{1}$} & \multicolumn{2}{|c|}{$\begin{array}{c}\text { Yellow } \\
\text { pan traps }^{2}\end{array}$} & \multirow{2}{*}{$\begin{array}{c}\text { Light } \\
\text { trap }^{3} \\
1991 \\
\end{array}$} \\
\hline & 1991 & 1992 & 1991 & 1992 & 1991 & 1992 & \\
\hline Coniopteryx pygmaea Enderlein & 0 & 1 & 0 & 0 & 0 & 0 & - \\
\hline Coniopteryx renate Rausch et Aspöck & 7 & 31 & 0 & 0 & 0 & 0 & - \\
\hline Coniopteryx tineiformis Curtis & 4 & 21 & 0 & 0 & 0 & 0 & - \\
\hline Helicoconis pseudolutea $\mathrm{Ohm}$ & 4 & 13 & 0 & 0 & 0 & 0 & - \\
\hline Parasemidalis fuscipennis Reuter & 0 & 1 & 0 & 0 & 0 & 0 & - \\
\hline Semidalis aleyrodiformis Stephens & 18 & 33 & 0 & 0 & 0 & 0 & - \\
\hline \multicolumn{8}{|l|}{ Hemerobiidae } \\
\hline Hemerobius humulinus Linnaeus & 17 & 5 & 7 & 1 & 2 & 0 & 1 \\
\hline Hemerobius lutescens Fabricius & 35 & 17 & 10 & 2 & 0 & 0 & 14 \\
\hline Hemerobius micans Olivier & 0 & 5 & 0 & 3 & 0 & 0 & 0 \\
\hline Micromus angulatus Stephens & 0 & 0 & 2 & 4 & 0 & 0 & 23 \\
\hline Micromus lanosus Zeleny & 0 & 0 & 4 & 5 & 0 & 0 & 3 \\
\hline Micromus variegatus Fabricius & 0 & 0 & 0 & 1 & 0 & 0 & 2 \\
\hline Sympherobius elegans Stephens & 0 & 0 & 1 & 0 & 0 & 0 & 0 \\
\hline Sympherobius pygmaeus Rambur & 1 & 4 & 3 & 0 & 0 & 0 & 10 \\
\hline Wesmaelius betulinus Strom & 0 & 0 & 0 & 0 & 0 & 0 & 6 \\
\hline Wesmaelius subnebulosus Stephens & 1 & 1 & 2 & 0 & 1 & 0 & 1 \\
\hline \multicolumn{8}{|l|}{ Chrysopidae } \\
\hline Chrysopa dorsalis Burmeister & 0 & 2 & 0 & 0 & 0 & 0 & 0 \\
\hline Chrysopa formosa Brauer & 15 & 67 & 7 & 15 & 0 & 0 & 19 \\
\hline Chrysopa nigricostata Brauer & 0 & 3 & 0 & 0 & 0 & 0 & 0 \\
\hline Chrysopa pallens Rambur & 30 & 47 & 0 & 6 & 1 & 1 & 0 \\
\hline Chrysopa perla Linnaeus & 6 & 21 & 28 & 72 & 5 & 9 & 24 \\
\hline Chrysopa phyllochroma Wesmael & 1 & 0 & 0 & 0 & 0 & 0 & 30 \\
\hline Chrysopa viridana Schneider & 0 & 12 & 0 & 0 & 0 & 0 & 0 \\
\hline Chrysopa walkeri McLachlan & 0 & 0 & 1 & 0 & 0 & 0 & 2 \\
\hline Chrysoperla carnea Stephens & 187 & 287 & 11 & 13 & 31 & 2 & 41 \\
\hline Chrysotropia ciliata Wesmael & 2 & 0 & 0 & 0 & 0 & 0 & 0 \\
\hline Dichochrysa flavifrons Brauer & 2 & 7 & 0 & 0 & 1 & 0 & 0 \\
\hline Dichochrysa prasina Burmeister & 37 & 57 & 13 & 17 & 5 & 1 & 1 \\
\hline Hypochrysa elegans & 0 & 0 & 0 & 1 & 0 & 0 & 0 \\
\hline Nineta flava Scopoli & 1 & 0 & 0 & 0 & 0 & 0 & 0 \\
\hline Nothochrysa fulviceps Stephens & 1 & 2 & 0 & 0 & 0 & 0 & 0 \\
\hline Peyerimhoffina gracilis Schneider & 0 & 1 & 0 & 0 & 0 & 0 & 0 \\
\hline Abundance (without Coniopterygidae) & 338 & 540 & 121 & 171 & 59 & 15 & 177 \\
\hline Number of species & 22 & 28 & 16 & 16 & 9 & 5 & 14 \\
\hline
\end{tabular}

1 in case of Malaise traps, the data of two traps are pooled

2 in case of yellow pan traps the data of five traps are pooled

3 in case of light trap catches the species of Coniopterygidae family were not considered. 
Table 2

Number of Neuroptera species and individual densities in function of different sampling methods applied. Nagykovácsi, 1991 and 1992

\begin{tabular}{|c|c|c|c|c|c|c|c|}
\hline & \multicolumn{2}{|c|}{ Suction trap } & \multicolumn{2}{|c|}{ Malaise traps ${ }^{1}$} & \multicolumn{2}{|c|}{$\begin{array}{c}\text { Yellow } \\
\text { pan traps }{ }^{2}\end{array}$} & \multirow{2}{*}{$\begin{array}{c}\text { Ligh } \\
\text { trap } \\
1991 \\
1991\end{array}$} \\
\hline & 1991 & 1992 & 1991 & 1992 & 1991 & 1992 & \\
\hline \multicolumn{8}{|l|}{ No. of species } \\
\hline Raphidiidae & 1 & 1 & 2 & 4 & 2 & 1 & 0 \\
\hline Inocellidae & 0 & 0 & 2 & 0 & 0 & 0 & 0 \\
\hline Coniopterygidae & 7 & 11 & 0 & 0 & 0 & 0 & - \\
\hline Hemerobiidae & 4 & 5 & 7 & 6 & 2 & 0 & 8 \\
\hline Chrysopidae & 10 & 11 & 5 & 5 & 5 & 4 & 6 \\
\hline \multicolumn{8}{|l|}{ No. of individuals } \\
\hline Raphidiidae & 2 & 2 & 30 & 31 & 13 & 2 & 0 \\
\hline Inocellidae & 0 & 0 & 2 & 0 & 0 & 0 & 0 \\
\hline Coniopterygidae & 137 & 291 & 0 & 0 & 0 & 0 & - \\
\hline Hemerobiidae & 54 & 32 & 29 & 16 & 3 & 0 & 60 \\
\hline Chrysopidae & 282 & 506 & 60 & 124 & 43 & 13 & 117 \\
\hline
\end{tabular}

1 in case of Malaise traps, the data of two traps are pooled

${ }^{2}$ in case of yellow pan traps the data of five traps are pooled

${ }^{3}$ in case of light trap catches the species of Coniopterygidae family were not considered.

It is remarkable that species belonging to the family Coniopterygidae were present only in the suction trap (Table 2, Fig. 1) compared to the Malaise traps and yellow pan traps.

The Raphidiidae were significantly underestimated by the suction trap compared to the Malaise traps and the yellow pan traps (Table 2, Fig. 1). The Raphidiidae material caught in the Malaise and pan traps were considerable; both as regards the collected number of individuals and in case of Malaise trap the species number (4 species). In the light trap Raphidioptera species did not occur (Table 2).

By studying the family Hemerobiidae it can be stated that neither the light trap nor the suction trap did not show significant differences. The sizes of samples collected by the two Malaise traps fell significantly behind the two latter methods. The best results were shown by the light trap as far as the species numbers are concerned ( 8 species). The two Malaise traps ( 7 and 6, respectively, in course of the two years 9 species in total) were found more effective than the suction trap (4 and 5, respectively, in course of two years 5 Hemerobiidae species in total). The yellow pan traps were not found suitable to collect species of Hemerobiidae (Table 2).

The suction trap surpassed the other trapping methods as members of the Chrysopidae family are concerned. For individual numbers the suction traps were followed by the light traps, Malaise traps and yellow pan traps (Table 2, Fig. 1). The suction trap was also superior to other methods as far as the numbers of species were collected. The Malaise traps yielded samples similar to light traps and exceeded the species richness of yellow pan traps only by few species. The yearly fluctuations of individual numbers were the highest in yellow traps (Table 2). 


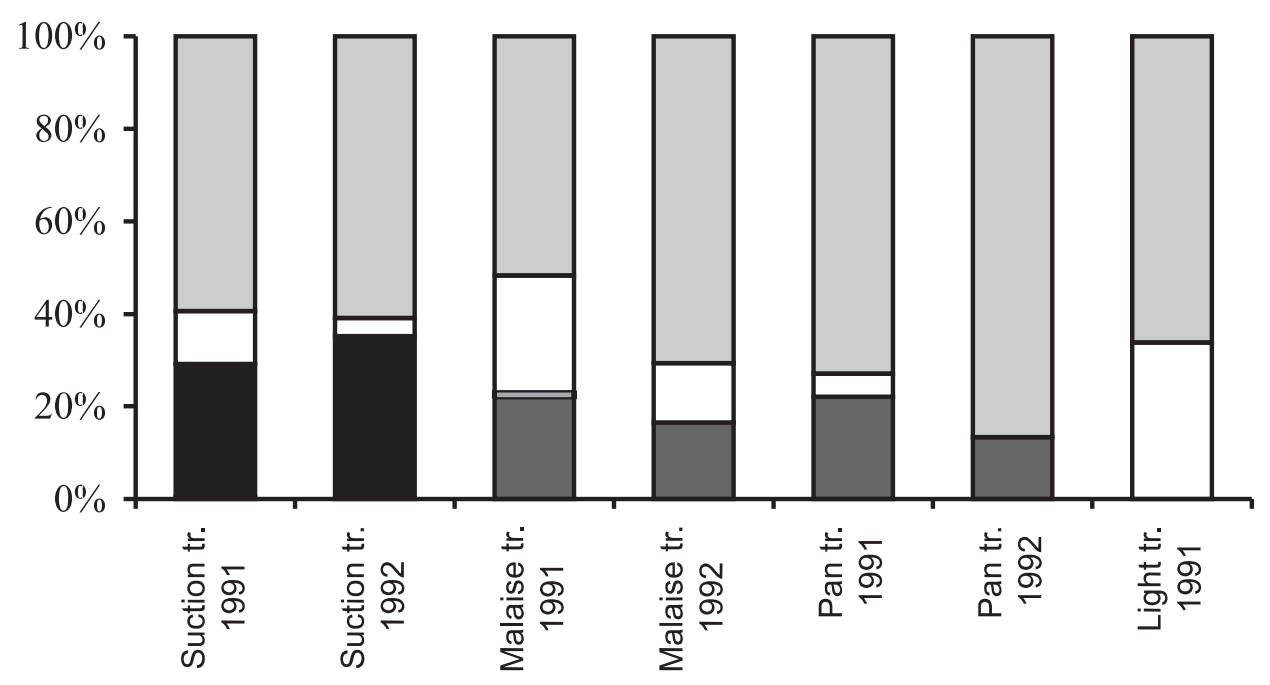

\section{Raphidiidae $\square$ Inocellidae $\square$ Coniopterygidae $\square$ Hemerobiidae $\square$ Chrysopidae}

Fig. 1. Dominance of different families, plotted against different collecting methods (From the material collected by light traps the species of Coniopterygidae were not selected out)

By looking separately the individual species of Raphidiidae and Coniopterygidae we find that conclusions established for families are also valid for species. The members belonging to Raphidiidae were collected to a higher degree by Malaise traps compared to suction trap and light traps whereas Malaise traps and yellow pan traps did not contain members of the Coniopterygidae family (Table 1).

Within the family Hemerobiidae the species Hemerobius lutescens was the most frequent in the suction traps in both years, while the Malaise and light traps showed its relative frequency much lower (Table 3). Micromus lanosus was not collected by suction traps in either year. In the light trap Hemerobius lanosus was under-represented while Micromus angulatus and, to a smaller extent, Sympherobius pygmaeus was over-represented compared to other trap types, especially to suction traps (Tables 1 and 3 ).

Within the family Chrysopidae, the species Chrysopa formosa was collected by all trap types with similar frequency (Table 3). The suction trap over-represented the species Chrysopa pallens and Chrysoperla carnea, as compared to other trap types. The light trap over-represented Chrysopa phyllochroma and under-represented Dychchrysa prasina. In Malaise traps the individual numbers of Chrysopa perla were significantly over-represented, while Chrysoperla carnea was under-represented, compared to other trap types (Tables 1 and 3). The yellow pan traps collected the species Chrysopa perla, Chrysoperla carnea and Dichochrysa prasina with higher frequencies, although the total individual number stayed quite low and the results of different years were very dissimilar. Although results of yellow pan traps were not shown in Table 3, it could be established that 


\section{Table 3}

Relative densities of Hemerobiidae and Chrysopidae species, in function of different sampling methods applied. Those that showed higher densities are shown by grey colour $($ total Hemerobiidae $=1$, total Chrysopidae $=1)$

\begin{tabular}{|c|c|c|c|c|c|}
\hline & $\begin{array}{c}\text { Suction tr. } \\
1991\end{array}$ & $\begin{array}{c}\text { Suction tr. } \\
1992\end{array}$ & $\begin{array}{c}\text { Malaise tr. } \\
1991\end{array}$ & $\begin{array}{c}\text { Malaise tr. } \\
1992\end{array}$ & $\begin{array}{c}\text { Light tr. } \\
1991\end{array}$ \\
\hline \multicolumn{6}{|l|}{ Hemerobiidae } \\
\hline Hemerobius humulinus & 0.31 & 0.16 & 0.24 & 0.06 & 0.02 \\
\hline Hemerobius lutescens & 0.65 & 0.53 & 0.34 & 0.12 & 0.23 \\
\hline Micromus lanosus & 0 & 0 & 0.13 & 0.31 & 0.05 \\
\hline Micromus angulatus & 0 & 0 & 0.06 & 0.25 & 0.38 \\
\hline Sympherobius pygmaeus & 0.02 & 0.13 & 0.10 & 0 & 0.17 \\
\hline \multicolumn{6}{|l|}{ Chrysopidae } \\
\hline Chrysopa formosa & 0.05 & 0.13 & 0.12 & 0.12 & 0.16 \\
\hline Chrysopa pallens & 0.11 & 0.09 & 0 & 0.04 & 0 \\
\hline Chrysopa perla & 0.02 & 0.04 & 0.47 & 0.57 & 0.21 \\
\hline Chrysopa phyllochroma & 0 & 0 & 0 & 0 & 0.26 \\
\hline Chrysoperla carnea & 0.66 & 0.57 & 0.18 & 0.1 & 0.35 \\
\hline Dichochrysa prasina & 0.13 & 0.11 & 0.22 & 0.13 & 0.01 \\
\hline
\end{tabular}

the traps did not under-represented Chrysopa perla $\left(\mathrm{p}_{i 1991}=0.12\right.$ and $\mathrm{p}_{i 1992}=0.69-$ when the total number of Chrysopidae collected in 1991 or in 1992 is 1.0) compared to suction traps and Dichochrysa prasina $\left(\mathrm{p}_{i 1991}=0.12\right.$ and $\left.\mathrm{p}_{i 1992}=0.08\right)$ as compared to the light trap.

If the data of suction traps are regarded as the least distorted ones - owing to the fact that this trap types do not exert any attractive influence on flying insects and only the ones just happen to fly over the trap are sucked - in by accident - we can establish that in Malaise traps compared to suction traps the species Hemerobius humulinus, Hemerobius lutescens, Chrysopa pallens and Chrysoperla carnea were significantly under-represented (Table 3), while Micromus lanosus and Chrysopa perla were heavily over-represented. Similarly, the light traps significantly under-represented the species Hemerobius humulinus, Hemerobius lutescens, Chrysopa pallens and Chrysoperla carnea and Dichochrysa prasina and over-represented the species Micromus angulatus, Sympherobius pygmaeus and Chrysopa phyllochroma (Table 3).

By studying the diversity conditions of lacewing assemblages by using Rényidiversity and by excluding Coniopterygidae it was established that the diversities of samples got by suction trap and yellow pan trap are especially lower than the ones collected by Malaise trap and light trap (Figs 2 and 3, Tables 4 and 5). The diversities of Neuroptera assemblages collected by Malaise and light traps showed significant differences only at the begin of scale parameter, in the section sensitive to rare species, contrary to other sections of the scale parameter (Figs 2 and 3, Tables 4 and 5).

If by evaluating the diversities of suction trap catches also the species belonging to Coniopterygidae were considered, then the diversity of Neuropteroidea assemblage had increased and only on that section of the scale parameter fell behind the diversity of 
Malaise trap and light trap catch where it was sensitive to frequent or medium frequent species (1991) or the scale parameter in its whole length did not differ from the diversity shown by the Malaise trap (1992).

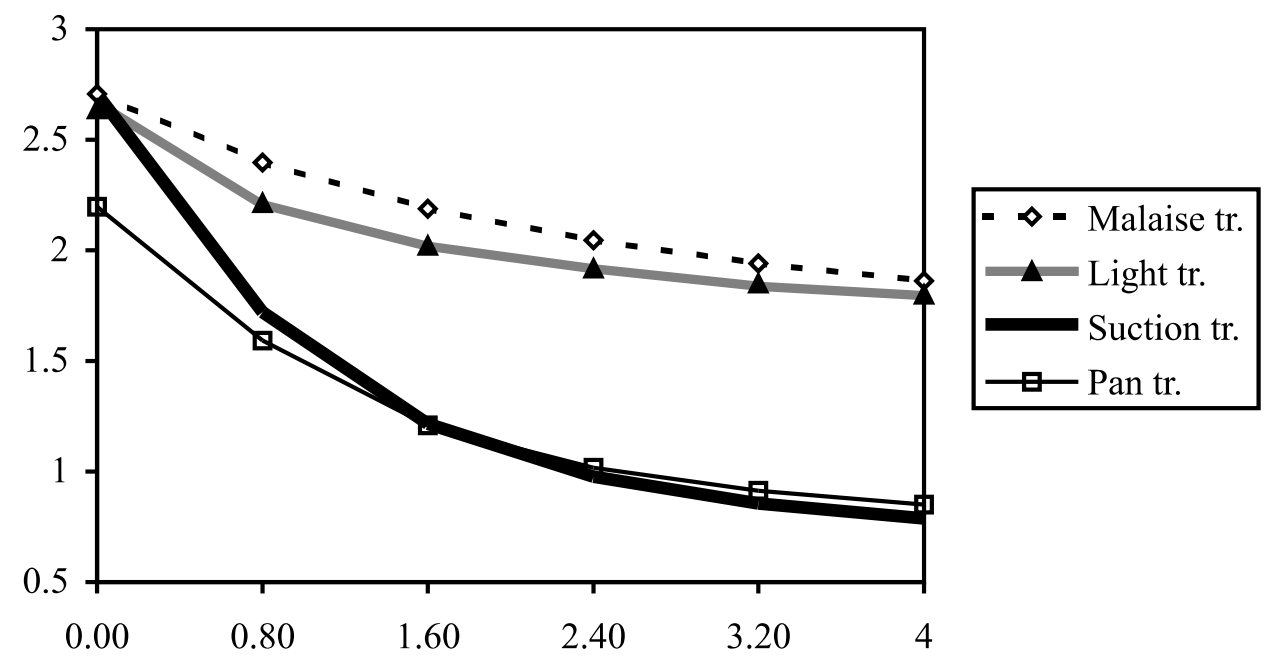

Fig. 2. Rényi-diversity profiles of Neuroptera assemblages collected by different methods. Nagykovácsi, 1991 (The Coniopterygidae were excluded from the sampling data of suction traps)

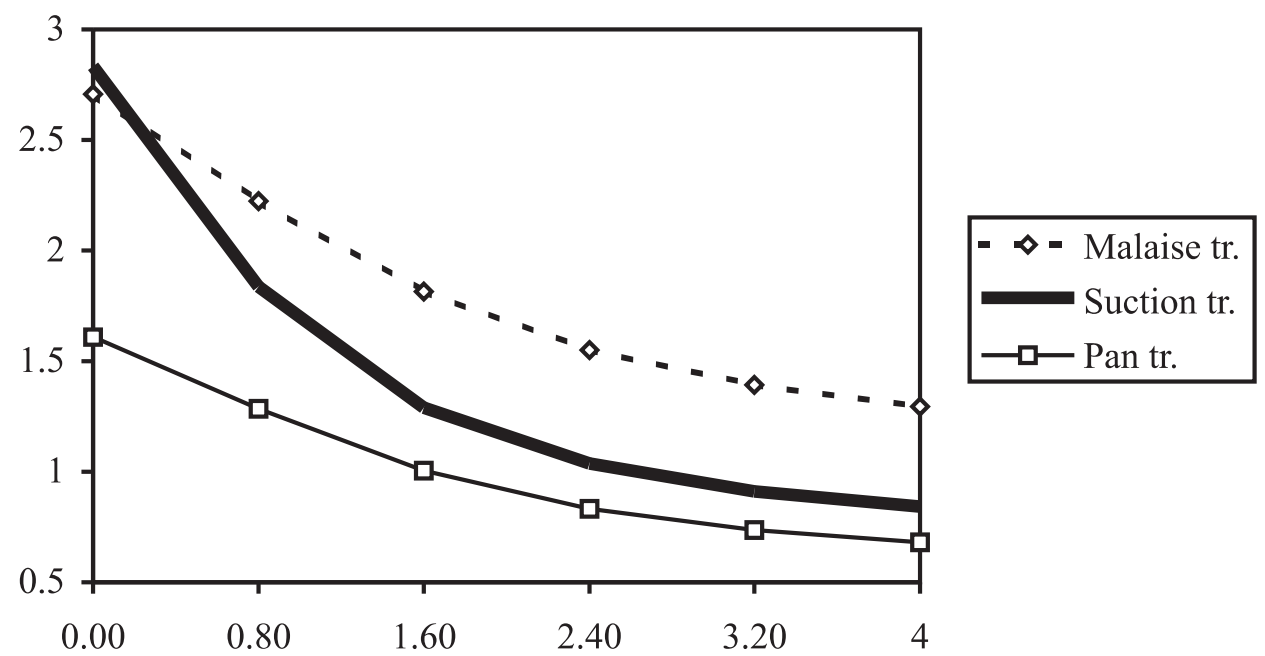

Fig. 3. Rényi-diversity profiles of Neuroptera assemblages collected by different methods. Nagykovácsi, 1992 (The Coniopterygidae were excluded from the sampling data of suction traps) 
The similarities of Neuropteroidea assemblages observed by different trapping methods were studied with the Horn index. Both the hierarchical classification (Fig. 4) and ordination (Fig. 5) showed significant segregation in the samples collected by suction, Malaise and light traps. The assemblages collected by yellow pan traps did not exhibit definite character: in 1991 the collected material resembled the one of suction trap, in 1992 more to the one found in Malaise traps.

\section{Table 4}

Comparison of Rényi diversities of Neuroptera assemblages collected by different methods in 1991 by t-test $\left({ }^{*} \mathrm{p}<0.05,{ }^{* *} \mathrm{p}<0.01\right.$, n.s. $=$ non-significant, $\mathrm{t}$-values $)$

\begin{tabular}{lrrrrr}
\hline & 0.8 & \multicolumn{1}{c}{1.6} & 2.4 & 3.2 & 4 \\
\hline Suction tr. - Malaise tr. & $* * 7.2267$ & $* * 7.5233$ & $* * 6.8563$ & $* * 6.1441$ & $* * 5.6064$ \\
Suction tr. - Pan tr. & n.s. 0.9381 & n.s. 0.0385 & n.s. 0.2263 & n.s. 0.3279 & n.s. 0.3660 \\
Suction tr. - Light tr. & $* * 5.9745$ & $* * 8.1984$ & $* * 8.9013$ & $* * 8.8250$ & $* * 8.3787$ \\
Malaise tr. - Pan tr. & $* * 5.6825$ & $* * 5.1661$ & $* * 4.8272$ & $* * 4.4932$ & $* * 4.2343$ \\
Malaise tr. - Light tr. & $* 2.0776$ & n.s. 1.3584 & n.s. 0.8087 & n.s. 0.4867 & n.s. 0.3039 \\
Pan tr. - Light tr. & $* * 4.6233$ & $* * 4.7707$ & $* * 5.0174$ & $* * 5.0965$ & $* * 5.0742$ \\
\hline
\end{tabular}
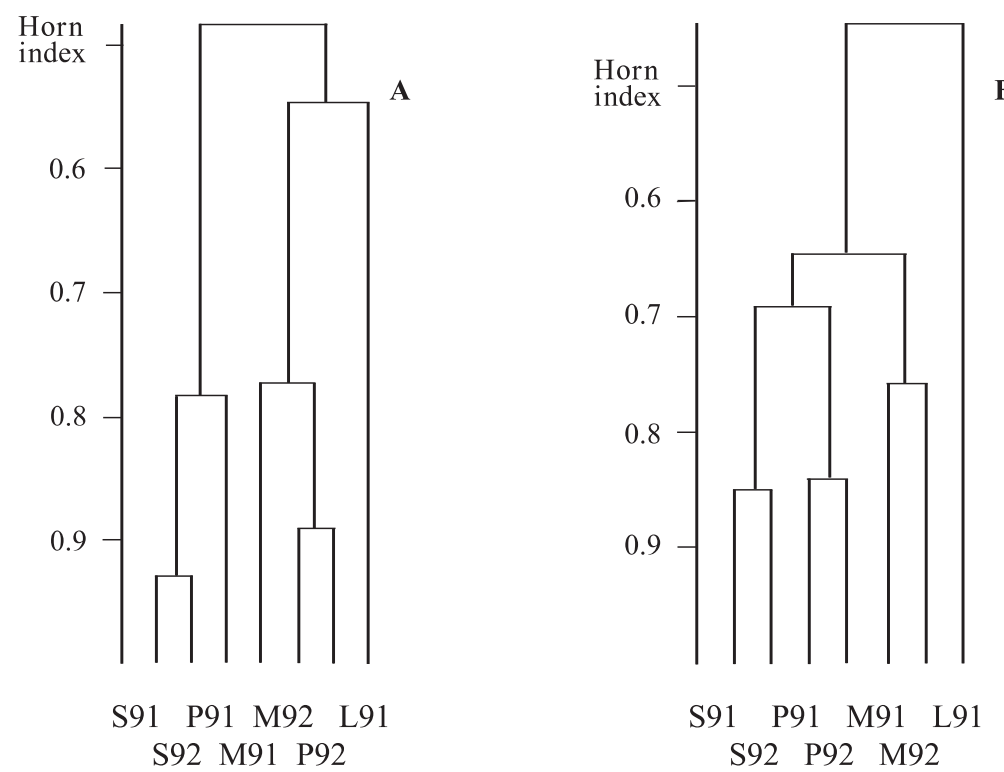

Fig. 4. The similarities of Neuroptera assemblages collected by different trapping methods and compared by hierarchical clustering (Nagykovácsi, 1991-1992). A: Complete link,

Horn index B: the same, but with standardisation $\left(\log _{10}\right)$

(The Coniopterygidae were excluded from the sampling data of suction trap) 


\section{Table 5}

Comparision of Rényi diversities of Neuroptera assemblages collected by different methods in 1992 by t-tests, Nagykovácsi

(+: $\mathrm{P}<0.1,{ }^{*}: \mathrm{p}<0.05,{ }^{* *}: \mathrm{p}<0.01$, n.s.: non-significant; and t-values)

\begin{tabular}{lrrrrr}
\hline & 0.8 & 1.6 & 2.4 & 3.2 & 4 \\
\hline Suction tr. - Malaise tr. & $* * 3.5426$ & $* *-3.1649$ & $* * 2.7124$ & $* 2.5991$ & $* 2.4271$ \\
Suction tr. - Pan tr. & $* 2.8347$ & n.s. 0.9502 & n.s. 0.6565 & n.s. 0.5899 & n.s. 0.5721 \\
Malaise tr. - Pan tr. & $* * 4.4417$ & $* 2.4481$ & +2.0215 & +1.9008 & +1.8628 \\
\hline
\end{tabular}

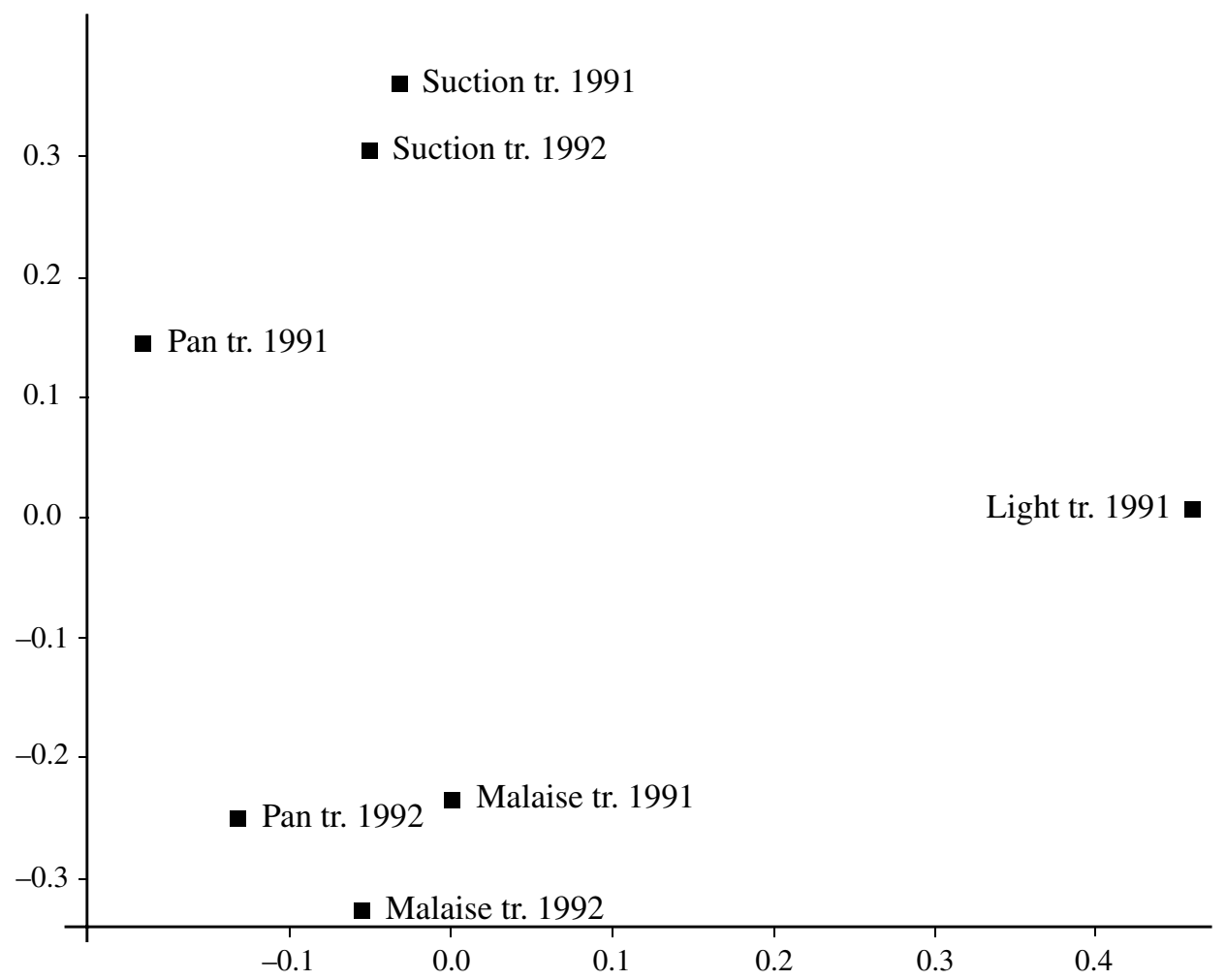

Fig. 5. Comparison of Neuroptera assemblages collected by different methods and evaluated by metric ordination (method of principal coordinates analysis, Horn index). Nagykovácsi, 1991-1992 (The Coniopterygidae were excluded from the sampling data of suction trap)

S 91 and S 92: suction traps in 1991 and 1992

M 91 and M 92: Malaise traps in 1991 and 1992

P 91 and P 92: pan traps in 1991 and 1992

L 91: light trap in 1991 


\section{Discussion}

According to our observations the collection of Raphidioptera assemblage is carried out mainly by Malaise traps or to a smaller extent by yellow pan traps, wich phenomenon may be in connection with their diurnal activity. For the collection of Coniopterygidae we have found the most suitable the suction traps while Malaise traps and yellow pans did not collect species belonging to this family. The results in case of Malaise traps are inconsistent with the experiences of Vidlicka $(1994,1995)$ who found in his Malaise traps more or less Coniopterygidae. In our case the diameter of guiding-wing (baffle) meshes of traps were wide enough ( 2 millimetres) for the trapped insects to escape. Although the Coniopterygidae of light traps were not singled out, this does not mean that they are not attracted by light. According to the literature (Williams and Killington, 1935) Coniopterygidae are well collected by light traps and we have observed the same in other habitats. From Hemerobiidae the light traps caught the majority of species. This trap type was recommended by Szabó and Szentkirályi (1981) and Szentkirályi (1992) to collect Hemerobiidae. In Chrysopidae the suction trap yielded 2.5 times more individuals than the light traps and 6-8 times more than the two Malaise traps; even the number of species was higher in case of the suction trap. Our results contradicted the ones of Szabó and Szentkirályi (1981) who found the best the light traps in collecting Chrysopidae in other habitats.

The Malaise and light traps yielded significantly distorted results and samples compared both to each other and to ones of suction traps. For example the Malaise traps over-represented the presence of Micromus lanosus, the opposite was true in case of $\mathrm{He}$ merobius species. At the same time the light trap over-emphasised the presence of Chrysopa phyllochroma compared to the other traps. It results from this that the structure of the samples are remarkably determined by the interactions between the species composition of the natural Neuropteroidea assemblages and the sampling method have been used.

Although there were significant fluctuations within populations in different years, these were equalised on assemblage level by using the same trap type; if however different traps were used, the significant differences caused separations in Neuropteran assemblages. The results of Malaise and suction traps kept constantly segregated from each other and from the assemblages collected by the light trap.

The latter (i. e. distortion of the light trap) results from the fundamental differences that these traps work during the dark phase, so the results are influenced by moonlight and by differences of various species in their attraction to light. While most species studied by us show a nocturnal activity (Duelli, 1986; Ábrahám and Vas, 1999; Vas et al., 1999), according to Bowden (1981) moonlight has decreased significantly the flying activity of Neuroptera. So the flight activity measured at full moon was not decreased only by the distorting effect of light traps used. A further effect may be caused by the insects themselves: a) the two sexes may be attracted by light to a different degree or b) the bad flyers do not reach the traps but make a landing earlier.

In case of Malaise traps, their functioning in absence of electricity and the high number of species attracted are unquestionable advantages that justified their general use. 
At the same time, the large white catching surfaces may exert influence towards different Neuropteroidea species. A further difference may be caused by behavioural differences that result from the behaviour of the insect by landing on the baffles (guiding surfaces). Our observations indicated that after landing the insects walk upward on these.

Although the yellow colour may be attractive to Neuropteroids (Maredia et al., 1992) the whole catching surface may be - even in case of many yellow pan traps - too small to yield large samples. This explains the fact that in our studies the yellow traps gave the smallest samples both in species numbers and individual numbers. However other distortions are possible: besides the mentioned visual effects it has to be mentioned that the yellow pans operate only during the daytime and also the liquid in the pans can influence the insects during the landing process.

Summarised, we can establish that the used methods determine fundamentally the picture showing up on Neuropteroidea assemblages. Plotted against the different methods used we may obtain different values on the relative frequencies, dominance orders, diversities and similarities of assemblages. Even if in the course of following studies the parallel collecting methods often cannot be applied, our results can help to choose the most adequate methods or to interpret correctly the results given by different sampling techniques.

\section{Acknowledgements}

The authors wish to express their thanks to Dr. Z. Mészáros and Dr. A. Haltrich for securing the background of studies described, to L. Kazinczy, Mrs L. Hornok and L. Zách for their help in trapping. For the critical comments of the manuscript we express our gratitude to Dr. F. Szentkirályi and Dr. L. Szalay-Marzsó. Our work has been supported by OTKA (No. 23885) and by the J. Bolyai Research Fund of the Hungarian Academy of Sciences.

\section{Literature}

Ábrahám, L. and Vas, J. (1999): Preliminary report on study of the daily activity pattern of Neuroptera in Hungary. Acta Phytopat. Entomol. Hung. 34, 153-164.

Balogh, J. (1953): A zoocönológia alapjai (Fundamentals of zoocoenology) Akadémiai Kiadó, Budapest, pp. 1-141.

Banks, C. J. (1952): An analysis of captures of Hemerobiidae and Chrysopidae in suction traps at Rothamsted, July 1949. Proc. R. ent. Soc. Lond. (A) 27, 45-57.

Bowden, J. (1981): The relationship between light- and suction-trap catches of Chrysoperla carnea (Stephens) (Neuroptera: Chrysopidae), and the adjustment of light-trap catches to allow for variations in moonlight. Bull. Ent. Res. 71, 621-629.

Canard, M., Neuenschwander, P. and Michelakis, S. (1979): Les Névreptéres capturés au piége de McPhail dans les oliviers en Gréce. 3. La Créte occidentale. Annls Soc. ent. Fr. N.S. 15, 607-615.

Duelli, P. (1986): Flight activity patterns in green lacewings (Planipennia: Chrysopidae). Recent Research in Neuropterology. Gepp, J., Aspök, H., Hölzel, H. (eds.), Graz, 165-170.

Greve, L. and Andersen, T. (1975): Neuroptera in light-traps at Osteroy, Hordaland. Norw. J. Ent. 22, 123-128. 
Jermy, T. (1961): Kártevő rovarok rajzásának vizsgálata fénycsapdákkal. A növényvédelem időszerű kérdései 1961 (Study of the activity of noxious insects by light trap. Recent problems of plant protection) 2, 53-60.

Krebs, C. J. (1989): Ecological methodology. Harper and Row Publishers, New York.

Maredia, K. M., Gage, S. H., Landis, D. A. and Wirth, T. M. (1992): Visual response of Coccinella septempunctata (L.). Hippodamia parenthesis (Say). (Coleoptera: Coccinellidae) and Chrysoperla carnea (Stephens). (Neuroptera: Chrysopidae) to colors. Biological-Control. 2, 253-256.

Meszleny, A. and Szalay-Marzsó, L. (1979): Data on Aphids (Homoptera, Aphidina) in Apple Orchard with Particular Emphasis on their Flight Dynamics and Natural Control Factors. Acta Phytopathologica Hungarica 14, 465-479.

Móczár, L. (1967): Önműködő csapda repülő rovarok számára (Trap automatic for capture of flying insects). Fol. ent. hung. 20, 214-222.

Muirhead-Thomson, R. C. (1991): Trap responses of flying insects. The influence of trap design on capture efficiency. Academic Press.

New, T. R. (1967): The flight activity of some British Hemerobiidae and Chrysopidae, as indicated by suction trap catches. Proc. R. ent. Soc. Lond. (A) 42, 93-100.

Rényi, A. (1961): On measure of entropy and information - Proceedings of the 4th Berkeley Symposium on Mathematical Statistics and Probability. (Ed. by J. Neumann) pp. 547-561. University of California Press, Berkeley.

Szabó, S. and Szentkirályi, F. (1981): Communities of Chrysopidae and Hemerobiidae (Neuroptera) in Some Apple - Ochrads. Acta Phytopat. Acad. Sci. Hung. 16, 157-169.

Szentkirályi, F. (1992): Spatio-temporal patterns of brown lacewings based on the Hungarian light trap network (Insecta: Neuroptera: Hemerobiidae). Current Research in Neuropterology. Proceedings of the Fourth International Symposium on Neuropterology. Bagnéres-de-Luchon, France 1991. In: Canard, M., Aspöck, H. and Mansell, M. W. (eds), Toulouse, France, 1992. pp. 349-357.

Sziráki, Gy. (1996): Ecological investigations of the Neuropteroidea of oak forests in Hungary (Insecta: Raphidioptera. Neuroptera). Pure and Applied Research Neuropterology. Proceedings of the Fifth International Symposium on Neuropterology, Cairo, Egypt, 1994. In: Canard, M., Aspöck, H. and Mansell, M. W. (eds), Toulouse, France, 1996. pp. 229-232.

Tóthmérész, B. (1995): Comparison of different methods for diversity ordering. Journal of Vegetation Science 6, 283-290.

Townes, H. (1962): Design for a Malaise trap. Proc. Entomol. Soc. Washington. 64, 253-262.

Vas, J., Ábrahám, L. and Markó, V. (1999): Study of nocturnal and diurnal activities of lacewings (Neuropteroidea, Raphidioptera, Neuroptera) by suction trap. Acta Phytopath. Acad. Sci. Hung. 34, 149-152.

Vidlicka, L. (1994): Flight activity of some Planipennia species. Biologia Bratislava 49, pp. 729-737.

Vidlicka, L. (1995): Seasonal flight activity of Planipennia species at the Devinska Kobyla hill (West Carpatians). Biologia Bratislava 50, pp. 151-156.

Williams, C. B. and Killington, F. J. (1935): Hemerobiidae and Chrysopidae in a light trap at Rothamsted experimental station. Trans. Soc. Br. Ent. 2, 145-150. 